\title{
NAGS HEAD RENOURISHMENT - PLANNING, DESIGN, AND NUMERICAL MODELING
}

\author{
Haiqing Liu Kaczkowski, PhD PE, Coastal Science \& Engineering, hk@coastalscience.com \\ Tim W Kana, PhD PG, Coastal Science \& Engineering, tkana@coastalscience.com \\ Ruben Visser, Delft University of Technology, r.visser93@gmail.com
}

\section{PROJECT BACKGROUND}

The 16 kilometer $(\mathrm{km})$ beach along Nags Head (North Carolina, USA) has sustained chronic erosion over the past 50 years. In 2011, 3.5 million cubic meters $\left(\mathrm{m}^{3}\right)$ of beach-quality sand was dredged from offshore and placed along the oceanfront at fill densities ranging from $150 \mathrm{~m}^{3} / \mathrm{m}$ to $400 \mathrm{~m}^{3} / \mathrm{m}$ (averages $220 \mathrm{~m}^{3} / \mathrm{m}$ ). It is the largest locally funded beach nourishment project completed to date in the U.S. Following successful completion of the project, the Town of Nags Head monitored performance and developed strategies for beach maintenance and preservation with the goal of improving protection to all properties and recreational beach area. The short-term plan is a renourishment anticipated to commence in the summer of 2018 or before the 2011 project reaches $50 \%$ fill remaining. The long-term plan targets a timeframe of 30 years. This abstract will focus on the short-term plan whose original purpose and goals are to supplement and enhance the initial 2011 project.

\section{PROJECT PLANNING}

Annual beach condition surveys in June for the first five years after the completion of the 2011 project show that the project area retained $\sim 90 \%$ of the nourishment sand as of June 2016 , and only $\sim 0.35$ million $\mathrm{m}^{3}$ of sand lost from the fill templates over the first five years. While the project overall performed better than expected during the first five years, erosion losses varied significantly from north to south in the range (+) $7 \mathrm{~m}^{3} / \mathrm{m} / \mathrm{yr}$ to (-) $50 \mathrm{~m}^{3} / \mathrm{m} / \mathrm{yr}$.

The 2011 project has withstood three major hurricanes and numerous fall and winter storms, and proved its worth with little damage to oceanfront properties and infrastructure. The latest hurricane, Matthew, impacted the project area on 8-9 October 2016. This storm produced high water levels, increased wave energy (significant waves > 5.2 meters), and brought strong winds as it approached to Nags Head. A comprehensive beach condition survey was conducted after Matthews passage, and the results show that $\sim 1.1$ million $\mathrm{m}^{3}$ of sand ( $\sim 30$ percent of the nourishment volume) shifted out of the fill templates after the storm from the foredune to $5.8 \mathrm{~m}$ NAVD. Depth of closure at decadal scale in this setting is approximately $-10 \mathrm{~m}$ NAVD.

Consistent with the short-term plan and maintenance threshold, the Town of Nags Head plans a 3 million $\mathrm{m}^{3}$ renourishment project along the same $16-\mathrm{km}$ oceanfront with an average fill density of $\sim 190 \mathrm{~m}^{3} / \mathrm{m}$. Nourishment sand will be excavated from two offshore borrow pits with a total area of 290 hectares (Figure 1).

\section{PROJECT DESIGN}

The numerical models STWAVE and GENESIS were used in the design of the 2011 project. The 2018 renourishment design draws on the previous numerical modeling experience, and implemented the Delft3D modeling suite to identify erosion hotspots, optimize the fill design, estimate the project longevity, and evaluate the impact of offshore borrow area dredging on longshore sediment transport. Compared to a one-line model like GENESIS, Delft3D integrates currents, waves, and sediment transport into the model and allows for a more realistic representation of nearshore, cross-shore, and longshore hydrodynamics and morphodynamics. The final design was refined by Delft3D to better account for the high erosion gradient from north to south along Nags Head. Delft3D model results show that a maximum increase in depth-averaged flow velocity is expected to be in the order of $\sim 0.15 \mathrm{~m}$ per second after the offshore borrow area dredging. The net result is expected to be a negligible impact on net longshore transport. This favorable finding is largely due to the varying wind and wave directions along Nags Head which limit sustained focusing of wave energy along any point on the shoreline. PhD PG

\section{CONCLUSION}

The 2011 Nags Head nourishment project has generally performed better than predicted (USACE 2010; Kaczkowski and Kana 2012). However, performance correlates with the historical gradients in erosion which vary from $<6 \mathrm{~m}^{3} / \mathrm{m}$ along the northern $10 \mathrm{~km}$ to $>25 \mathrm{~m}^{3} / \mathrm{m}$ at the southern $4 \mathrm{~km}$. The renourishment plan is focused on restoring sand losses since 2011 and particularly after Hurricane Matthew, while improving performance at the most rapidly eroding section of beach. Delft3D has provided more realistic simulations of alternative fill configurations and improved confidence in the renourishment design. It is also being used to evaluate alternatives to increase the renourishment interval and improve longevity over the long term.

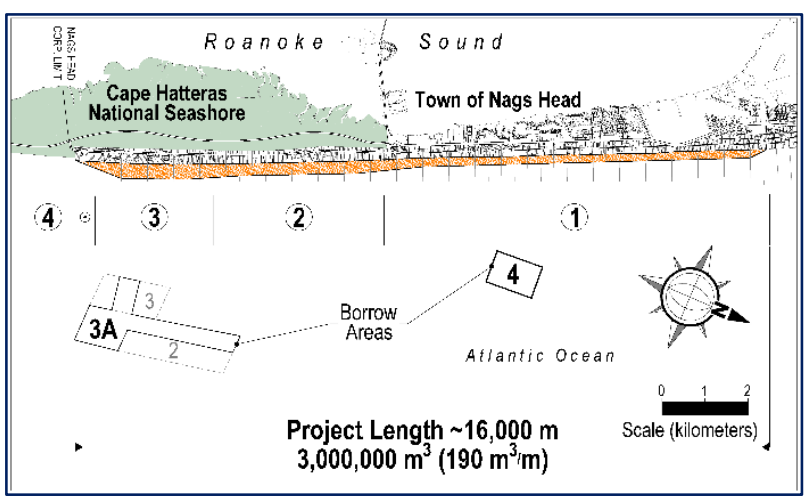

Figure 1 - Nags Head 2018 renourishment project map with Borrow Areas $3 \mathrm{~A}$ and 4 located $2-3 \mathrm{~km}$ offshore.

(Areas 2 and 3 were used in the 2011 project). Fill densities vary from north to south in the range of $150 \mathrm{~m} / \mathrm{m}$ to $387 \mathrm{~m}^{3} / \mathrm{m}$ with an average of $190 \mathrm{~m}^{3} / \mathrm{m}$.

\section{REFERENCES}

USACE (2010): Final environmental impact statement, beach nourishment project, Town of Nags Head, North Carolina. $164 \mathrm{pp}$ plus appendices.

Kaczkowski, Kana (2012): Final design of the Nags Head beach nourishment project using a long shore numerical model, International Conference on Coastal Engineering 2012 (Santander, Spain), ASCE, New York. 